\section{Toxic effects of vanadium in streptozotocin-treated rats after administration of vanadate to normalize blood glucose levels}

\section{Dear Sir,}

Recently O. Blondel et al. reported an insulin-like effect of vanadate upon glucose metabolism in vivo in the liver and peripheral tissues of streptozotocin-diabetic rats, leading to normalization of glycaemia in the absence of any significant improvement of insulin secretion [1].

The efficacy of oral administration of vanadate in normalizing blood glucose levels of streptozotocin-treated (ST) rats was previously investigated by other authors $[2,3]$. In all cases vanadate was effective in normalizing blood glucose levels. However, it was administered in drinking water at concentrations ranging between 200 and 800 parts per million (ppm), which are potentially toxic. Although Meyerovitch et al. [3] did not find signs of toxicity on the renal or hepatic function after oral vanadate treatment, other authors have reported increased levels of vanadium in several tissues after orthovanadate $(50 \mathrm{ppm} \mathrm{V})$ or sodium metavanadate $(50 \mathrm{ppm} \mathrm{NaV03)}$ administration $[4,5]$. Signs of renal toxicity were also observed at $50 \mathrm{ppm} \mathrm{NaV03} \mathrm{[5].} \mathrm{Moreover,} \mathrm{ammonium} \mathrm{meta-}$ vanadate decreased erythropoiesis and maturation of erythrocytes when given to rats in drinking water for a period of 2,4 or 8 weeks [6].

Due to the relatively high levels of vanadate given to rats $(200$ ppm) by Blondel et al. [1], we suggest that the toxic effects of vanadium should also be clearly evaluated. If tissue concentrations of vanadium are increased as seems likely, the use of chelating agents to remove the metal may be indicated [7].

Yours sincerely,

J.L. Domingo, J.M. Llobet and J. Corbella

\section{References}

1. Blondel O, Bailbe D, Portha B (1989) In vivo insulin resistance in streptozotocin-diabetic rats- evidence for reversal following oral vanadate treatment. Diabetologia 32: 185-190

2. Heyliger CE, Tahiliani AG, McNeill JH (1985) Effect of vanadate on elevated blood glucose and depressed cardiac performance of diabetic rats. Science 227: 1474-1477

3. Meyerovitch J, Farfel Z, Sack J, Shechter Y (1987) Oral administration of vanadate normalizes blood glucose levels in streptozotocin-treated rats. J Biol Chem 262: 6658-6662

4. Parker RDR, Sharma RP (1978) Accumulation and depletion of vanadium in selected tissues of rats treated with vanadyl sulfate and sodium orthovanadate. J Environ Pathol Toxicol 2: 235245

5. Domingo JL, Llobet JM, Tomas JM, Corbella J (1985) Shortterm toxicity studies of vanadium in rats. J Appl Toxicol 5: 418421
6. Zaporowska H, Wasilewski W (1989) Some selected peripheral blood and haemopoietic system indices in Wistar rats with chronic vanadium intoxication. Comp Biochem Physiol 93C: $175-180$

7. Domingo JL, Llobet JM, Tomas JM, Corbella J (1986) Influence of chelating agents on the toxicity, distribution and excretion of vanadium in mice. J Appl Toxicol 6:337-341

Dr. J.L. Domingo

Laboratory of Toxicology and Biochemistry

School of Medicine

San Lorenzo 21

E-43201 Reus

Spain

\section{Response from the authors}

Dear Sir,

The argumentation presented by Dr. Domingo et al. seems to infer that in our presentation of the data related to the vanadatetreated diabetic rats [1], we have eliminated the possibility of a toxic effect of oral vanadate. We would like to emphasize that such an assumption does not correspond to the aim of our paper. In fact, over the duration of our experimental protocol we have clearly identified in both non-diabetic and diabetic rats (Results section and Table 1) the possibilities: (1) that the treated rats did not drink at satiety at least at the begining of the oral treatments; this point has also been mentionned by Brichard et al. [2] using the same dose protocol and these authors have suggested that it may explain the presence of a marginal dehydration since the haematocrit values and serum urea are slightly elevated [2]; (2) that the treated rats had a slower weight gain in relationship to a decrease in food intake, thus suggesting an anorexic effect of vanadate; this point has also been observed by Brichard et al. [2].

Nevertheless, Brichard et al. have reported that oral vanadate over a 9-week period of administration did not impair the kidney and liver functions of the rats as assessed by measurements of serum concentrations of creatinine and transaminases [2]. In a more general point of view it is considered [3] that the toxicity of vanadium is high when given by injection, low by oral route and intermediate by the respiratory tract and it seems to be established that vanadate is not very toxic in humans when given orally [3]. Finally, we stress the point that the information supplied by our work is not aimed at justifying the use of vanadate salts as a therapeutic agent; but rather they clearly identify vanadate as an interesting tool to further characterize the impairment of glucose homeostasis in diabetes and more specifically the question of insulin resistance [4].

Yours sincerely, B. Portha and $\mathrm{O}$. Blondel 


\section{References}

1. Blondel O, Bailbe D, Portha B (1989) In vivo insulin resistance in streptozotocin-diabetic rats - evidence for reversal following oral vanadate treatment. Diabetologia 32: 185-190

2. Brichard S, Okitolonda W, Henquin JC (1988) Long term improvement of glucose homeostasis by vanadate treatment in diabetic rats. Endocrinology 123: 2048-2053

3. Nechay BR, Nanninga LB, Nechay PSE, Post RL, Grantham JJ, Macara IG, Kubena LF, Phillips TO, Nielsen FH (1986) Role of vanadium in biology. Fed Proc 45: 123-132
4. Blondel O, Chevalier B, Simon J, Portha B (1989) Impaired insulin action but normal insulin receptor activity in the liver of neonatal ( 5 days) streptozotocin diabetic rats. Effect of oral vanadate treatment. Diabetologia 32: 467 (Abstract)

Prof. B. Portha

Université Paris VII

Laboratoire de Physiologie

du Développement

2 Place Jussieu

F-75251 Paris Cedex 05

France

\section{Announcement}

\section{Diabetes and Exercise 90}

This international scientific symposium will be held in Düsseldorf from May 19-21, 1990. Co-sponsored by The World Health Organisation, European Association for the Study of Diabetes and the German Diabetes Association. Organising Committee: M.Berger (FRG), E. S. Horton (USA), N. B. Ruderman (USA), F. W. Kemmer (FRG). Participation limited to 100 colleagues, including a faculty of approximately 25 experts. The submission of abstracts (up to 500 words) for short communications and posters is encouraged; deadline March 1, 1990.

Address for information and submission of abstracts: Dr. M. Berger, Professor of Medicine, Department of Medicine E, Moorenstrasse 5, D-4000 Düsseldorf, FRG. 